\title{
ANALISIS INTERVENSI FISKAL TERHADAP KEMISKINAN (STUDI KASUS DANA DESA PULAU KALIMANTAN)
}

\section{AN ANALYSIS OF FISCAL INTERVENTION TOWARD POVERTY (A CASE STUDY OF VILLAGE FUNDS OF KALIMANTAN ISLANDS)}

\author{
M. Zaky Mubarak Lubis \\ Fakultas Ekonomi dan Bisnis Islam UIN Imam Bonjol Padang \\ Sungai Bangek, Kelurahan Balai Gadang, Kecamatan Koto Tangah, Padang \\ e-mail: buruangabung27@gmail.com \\ Aprian Subhan Dahraini \\ Fakultas Ekonomi dan Bisnis Islam UIN Syarif Hidayatullah \\ Ciputat \\ e-mail: dahraini@gmail.com
}

Naskah diterima 01 Mei 2018, di-review 01 Juni 2018, disetujui 22 Juni 2018

\begin{abstract}
One of the government's strategies to help the village become independent and autonomous is by giving the village funds. The funds which are allocated for the rural area are expected to support the implementation of the people's empowerment and the rural development, so that funds can improve the people's prosperity. The aim of the study is to figure out the influence of fiscal intervention which representated by village funds, its allocation, and part of local earning and retribution toward poverty representated by Poverty Rate of Residences or Cities in Kalimantan Islands during 2015-2017. This research used quantitative descriptive approach with Panel Data Model. The result showed of Fixed Effect Model regression; Village Fund, Village Fund Allocation, and part of Local Earning and Retribution have negative significant influence at Poverty Rate for 47 residences or Cities in Kalimantan Islands.
\end{abstract}

Keywords: Kalimantan Island, Poverty Rate, Village Fund, Village Fund Allocation, Local Earning and Retribution.

\begin{abstract}
Abstrak: Salah satu strategi pemerintah untuk membantu desa menjadi mandiri adalah dengan memberikan alokasi dana desa. Dana dialokasikan untuk daerah pedesaan, dan diharapkan untuk mendukung pelaksanaan pemberdayaan masyarakat dan pembangunan pedesaan, sehingga dana dapat meningkatkan kesejahteraan rakyat. Selanjutnya, tujuan penelitian ini untuk melihat pengaruh Intervensi Fiskal yang diwakili oleh dana desa, alokasi dana desa, dan bagian dari pendapatan dan retribusi daerah terhadap kemiskinan yang diwakili oleh tingkat kemiskinan perumahan/ kota di Pulau Kalimantan selama tahun 2015-2017. Penelitian ini menggunakan pendekatan deskriptif kuantitatif dengan Model Data Panel. Hasil penelitian menunjukkan bahwa regresi Model Efek Tetap, dana desa, alokasi dana desa, dan bagian pendapatan dan retribusi daerah berpengaruh negatif dan negatif terhadap tingkat kemiskinan untuk 47 tempat tinggal / kota di Pulau Kalimantan.
\end{abstract}

Kata kunci: Pulau Kalimantan, tingkat kemiskinan, dana desa, alokasi dana desa, pendapatan dan retribusi daerah.

\section{PENDAHULUAN}

D alam sebuah negara yang besar dan berbentuk kepulauan yang sangat banyak dan luas, keanekaragaman sumber daya antar daerah dan perekonomian daerah menjadi salah satu pokok permasalahan pemerintah Indonesia. Perbedaan sumber daya baik itu sumber daya alam maupun sumber daya ekonomi menyebabkan 
pengelolaan perekonomian daerah setiap daerah berbeda-beda, dan akan membuat kesulitan jika hal tersebut dilakukan oleh pemerintah pusat saja. Oleh karena itu, setelah era orde baru berakhir, pola pemerintahan Indonesia menerapkan kebijakan desentralisasi fiskal dan otonomi daerah. Penerapan desentralisasi fiskal dan otonomi daerah bertujuan untuk mengembangkan seluruh potensi ekonomi yang ada sehingga dapat memacu peningkatan aktivitas perekonomian di daerah yang pada akhirnya meningkatkan perekonomian nasional (Ayu, 2012).

Di sisi lain, desentralisasi fiskal tidak akan berguna jika tidak diikuti dengan kemampuan finansial yang cukup memadai oleh pemerintah daerah. Penerapan otonomi daerah yang telah digariskan dalam UU No. 33/2004, mensyaratkan adanya suatu perimbangan keuangan antara pemerintah pusat dan daerah, yang memiliki tujuan utama untuk memperkuat kondisi fiskal daerah dan mengurangi ketimpangan antar daerah. Perimbangan keuangan antara pemerintah pusat dan daerah adalah suatu sistem pembiayaan pemerintah dalam negara yang mencakup pembagian keuangan antara pemerintah pusat dan daerah, serta pemerataan antar daerah secara proporsional, adil, demokratis dan transparan (Ayu, 2012). Berdasarkan hal tersebut, tujuan utama dari perimbangan keuangan adalah terciptanya pemerataan pembangunan ekonomi di daerah.

Tujuan pembangunan ekonomi adalah untuk meningkatkan kesejahteraan masyarakat serta menciptakan distribusi pendapatan yang merata (Todaro dan Smith, 2016). Lebih lanjut, Todaro dan Smith (2016) mengumukakan bahwa kemiskinan terkait dengan masalah kekurangan pangan dan gizi, keterbelakangan pendidikan, kriminal, pengangguran, prostitusi, dan masalah-masalah lain yang bersumber dari rendahnya tingkat pendapatan perkapita penduduk.Olehkarenaitu. keberhasilan pemerintahan dalam mencapai tujuan pembangunan seringkali dinilai dari perubahan tingkat kemiskinan. World Bank (2008) mendefinisikan kemiskinan sebagai kekurangan dalam kesejahteraan, dan terdiri dari banyak dimensi. Ini termasuk berpenghasilan rendah dan ketidakmampuan untuk mendapatkan barang dasar dan layanan yang diperlukan untuk bertahan hidup dengan martabat. Kemiskinan juga meliputi rendahnya tingkat kesehatan dan pendidikan, akses masyarakat miskin terhadap air bersih dan sanitasi, keamanan fisik yang tidakmemadai, kurangnya suara, dan kapasitas memadai dan kesempatan untuk hidup yang lebih baik itu.

Sadar akan pentingnya permasalahan kemiskinan di daerah, pemerintah pusat selaku penanggung jawab utama perekonomian Indonesia memiliki andil yang besar dalam pengentasan kemiskinan, salah satunya adalah kebijakan fiskal. Dalam mekanisme fiskal, pengelolaan keuangan melalui APBN diharapkan dapat mengurangi tingkat kemiskinan, salah satunya adalah dana perimbangan. Dana perimbangan bertujuan mengurangi kesenjangan fiskal antara pemerintah dan pemerintah daerah dan antar pemerintah daerah (UU Nomor 33 Tahun 2004). Bentuk komitmen pemerintah pusat dalam dana perimbangan adalah dengan mengalokasikan anggaran transfer fiskal ke daerah dalam APBN, yaitu terdiri dari Dana Bagi Hasil (DBH), Dana Alokasi Umum (DAU), dan Dana Alokasi Khusus (DAK). Kebijakan pengalihan sebagian kewenangan pengelolaan keuangan kepada pemerintah daerah yang diikuti dengan 
adanya transfer fiskal pada dasarnya bertujuan untuk efisiensi penyediaan pelayanan sektor publik di daerah terutama infrastruktur agar dicapai kesejahteraan masyarakat yang lebih baik. Hal ini karena pemerintah daerah dianggap lebih mengetahui kondisi masyarakatnya di daerahnya, sehingga diharapkan akan menciptakan layanan publik yang lebih baik.

Perbedaan mencolok yang terdapat di daerah adalah mengenai ketimpangan perekonomian perkotaan dan pedesaan. Daerah pedesaan sangat luas wilayahnya, sebagian besar penduduknya hidup di sektor pertanian dalam arti luas meliputi sub-sub sektor tanaman pangan, perkebunan, perikanan, peternakan, dan kehutanan. Tingkat kesejahteraan penduduk, ketersediaan prasarana, tingkat produktivitas, pendidikan, derajat kesehatan, ketersediaan kemudahan fasilitas ekonomi yang ada desa cenderung lebih rendah dibandingkan dengan daerah perkotaan.

Tabel 1.

Jumlah Penduduk Miskin di Indonesia (Juta Jiwa)

\begin{tabular}{lrrr}
\hline Wilayah & 2015 & 2016 & 2017 \\
\hline Perkotaan & 10,62 & 10,49 & 10,67 \\
Pedesaan & 17,89 & 17,28 & 16,31 \\
\hline
\end{tabular}

Sumber: di olah BPS 2018

Berdasarkan tabel 1 ditemukan bahwa jumlah penduduk miskin di Indonesia lebih banyak pada daerah pedesaan dibanding dengan daerah perkotaan. Masyarakat pedesaan terbalut dalam lingkaran kemiskinan struktural dan kultural. Permasalahan kurangnya modal, rendahnya tingkat pendidikan dan pengetahuan, minimnya infrastruktur, kurang memadainya fasilitas kesehatan menjadi sumber dari kemiskinan masyarakat pedesaan. Selain itu, kemiskinan kultural juga terjadi di pedesaan, budaya masyarakat pedesaan cenderung memilih pola hidup yang sederhana dan pasrah terhadap kondisi kemiskinannya. Hal ini merupakan efek domino kemiskinan struktural yang menghinggapi masyarakat terlalu lama, atau secara tidak langsung menunjukkan adanya keterkaitan antara kemiskinan struktural yaitu minimnya pembangunan pedesaan dengan kemiskinan kultural sehingga membuat masyarakat apatis, pasrah, dan berpandangan jika sesuatu yang terjadi adalah takdir (Rahmatullah dalam Kerta Adhi, 2016: t.h.).

Pada saat zaman orde baru, era sentralistik membuat pembangunan di desa menjadi seragam oleh pemerintah pusat. Program pembangunan desa lebih bersifat top-down, pemerintah pusat mengatur semua mekanisme pembangunan desa. Dalam era otonomi daerah, lahirnya UU No. 6 Tahun 2014 tentang Desa menegaskan saat ini pembangunan desa lebih diserahkan kepada desa itu sendiri. Otonomi desa tidak lagi menjadi sisa dari otonomi daerah kabupaten/kota (bersumber dari pemberian kabupaten), namun desa diberi keleluasaan untuk membangun desanya sesuai dengan potensi pendapatan asli desa tersebut. Meskipun demikian, pemerintah pusat dan pemerintah daerah tetap memiliki peran sebagai sebatas pada fasilitator, pemberi bantuan dana, pembinaan dan pengawasan dan evaluator.

Kebijakan fiskal memiliki dampak yang masif bagi perekonomian suatu negara, peningkatan Analisis Intervensi Fiskal terhadap Kemiskinan $\| 25$ 
atau penurunan APBN mempunyai efek multiplier terhadap keseimbangan perekonomian nasional. Oleh karena itu, salah satu bentuk fasilitas yang diberikan oleh pemerintah pusat melalui mekanisme kebijakan fiskal adalah program Dana Desa. Berdasarkan UU Desa, menyatakan bahwa pembangunan desa bertujuan meningkatkan kesejahteraan masyarakat desa dan kualitas hidup manusia serta penanggulangan kemiskinan melalui pemenuhan kebutuhan dasar, pembangunan sarana dan prasarana desa, pengembangan potensi ekonomi lokal, serta pemanfaatan sumber daya alam, dan lingkungan secara berkelanjutan. Dengan kata lain, diharapkan bahwa kebijakan fiskal pemerintah pusat melalui mekanisme dana desa ini pada akhirnya dapat menanggulangi kemiskinan di Indonesia melalui pembangunan di desa.

Tabel 2.

Persentase Penduduk Miskin di Indonesia (\%)

\begin{tabular}{lrrr}
\hline Wilayah & 2015 & 2016 & 2017 \\
\hline Sumatera & 12,34 & 11,98 & 11,77 \\
Jawa & 11,32 & 10,91 & 10,70 \\
Bali dan Nusa Tenggara & 17,86 & 17,35 & 17,05 \\
Kalimantan & 6,62 & 6,46 & 6,46 \\
Sulawesi & 12,36 & 12,14 & 12,09 \\
Maluku dan Papua & 25,13 & 25,01 & 24,40 \\
\hline
\end{tabular}

Sumber: di olah BPS 2018

Dana desa dimulai pada tahun 2015 dengan jumlah alokasi sebesar 20,766 triliun, kemudian naik menjadi 46,982 triliun pada tahun 2016 dan menjadi 60 triliun pada 2017. Terjadi kenaikan yang cukup signifikan sejak program dana desa pertama kali diluncurkan, naik hampir300\%, namun berdasarkan tabel 2 mengenai persentase penduduk miskin di Indonesia, nampaknya kucuran dana melimpah dari program dana desa ini dapat dikatakan belum efektif. Pada tahun 2015 hingga tahun 2017, jumlah penurunan persentase penduduk miskin dari yang paling besar hingga terkecil berturut-turut dimiliki oleh Pulau Bali dan Nusa Tenggara sebesar 0,81\%, kemudian wilayah Pulau Maluku dan Papua dengan 0,71\%, disusul Pulau Jawa dengan 0,62\%, Pulau Sumatera dengan 0,57\%, Pulau Sulawesi dengan $0,27 \%$, dan paling kecil perubahan persentase penduduk miskin adalah Pulau Kalimantan dengan perubahan sebesar $0,16 \%$.
Dengan adanya Dana Desa, maka desa memiliki kepastian pendanaan sehingga pembangunan dapat terus dilaksanakan tanpa harus terlalu lama menunggu datangnya dana bantuan dari pemerintah pusat. Pemberian dana desa merupakan wujud dari pemenuhan hak desa untuk melaksanakan otonominya sendiri secara mandiri. Hal ini dilakukan agar desa dapat bertumbuh dan berkembang sesuai dengan pertumbuhan desa itu sendiri berdasarkan keanekaragaman, otonomi asli, partisipasi, demokratisasi, pemberdayaan masyarakat dan meningkatkan peran Pemerintahan Desa dalam memberikan pelayanan yang lebih baik kepada warga desanya. Sehingga kesejahteraan masyarakat meningkat dan mempercepat laju pembangunan nasional.

Namun melihat fakta bahwa tingkat persentase penduduk miskin di Indonesia, terutama di Pulau Kalimantan yang turun hanya 
0,16\% setelah penyelenggaraan 3 dana desa tahun, dapat dikatakan bahwa tujuan utama peningkatan kesejahteraan masyarakat belum terpenuhi. Dengan kata lain, pembangunan desa dan daerah yang menjadi prioritas utama pemerintahan melalui kucuran dana desa belum memiliki dampak yang signifikan peningkatan taraf hidup dalam masyarakat desa. Meskipun demikian, dana desa tetap memiliki potensi untuk menurunkan tingkat kemiskinan. Oleh karena itu, studi ini dianggap perlu dilakukan dengan pemikiran bahwa; pertama, terdapat pengaruh antara transfer fiskal melalui dana desa terhadap kemiskinan di daerah, kedua terdapat faktorfaktor non-ceteris paribus yang mengakibatkan penurunan persentase jumlah penduduk miskin di Pulau Kalimantan sangat sedikit.

\section{Kerangka Konseptual}

\section{Kebijakan Fiskal}

Kebijakan fiskal merupakan salah satu kebijakan ekonomi makro yang otoritas utamanya berada di tangan pemerintah dan diwakili oleh Kementerian Keuangan. Hal tersebut diatur dalam dalam Undang-Undang Nomor 17 Tahun 2003 tentang Keuangan Negara, yang menyebutkan bahwa presiden memberikan kuasa pengelolaan keuangan dan kekayaan negara kepada Menteri Keuangan selaku pengelola fiskal dan wakil pemerintah dalam pemilikan kekayaan negara yang dipisahkan. Kebijakan fiskal umumnya merepresentasikan pilihan-pilihan pemerintah dalam menentukan besarnya jumlah pengeluaran atau belanja dan jumlah pendapatan, yang secara eksplisit digunakan untuk mempengaruhi perekonomian.
Berbagai pilihan tersebut, dalam tataran praktisnya dimanifestasikan melalui anggaran pemerintah, yang di Indonesia lebih dikenal dengan Anggaran Pendapatan dan Belanja Negara (APBN).

Definisi lain meyebutkan, kebijakan fiskal adalah kebijakan yang dilakukan pemerintah berkaitan dengan penerimaan (pendapatan) dan pengeluaran (belanja) uang pemerintah (Basri, 2003: t.h.). Secara singkat dapat dikatakan bahwa kebijakan fiskal adalah, kegiatan yang dilakukan pemerintah sebagai salah satu bentuk intervensi untuk mengelola anggaran dalam mempengaruhi perekonomian serta memaksimumkan kesejahteraan dan stabilitas dalam bidang perekonomian. Pengeluaran pemerintah mencerminkan kebijakan pemerintah apabila pemerintah telah menetapkan suatu kebijakan untuk membeli barang dan jasa. Pengeluaran pemerintah mencerminkan biaya yang harus dikeluarkan oleh pemerintah untuk melaksanakan kebijakan tersebut. Pengeluaran pemerintah dapat dinilai dari berbagai segi sehingga dapat dibedakan menjadi: (Suparmoko, 2012: t.h.):

1. Pengeluaran itu merupakan investasi yang menambah kekuatan dan ketahanan ekonomi di masa-masa yang akan datang. Pengeluaran itu langsung memberikan kesejahteraan dan kegembiraan bagi masyarakat. Merupakan penghematan pengeluaran yang akan datang. Menyediakan kesempatan kerja lebih banyak dan penyebaran tenaga beli yang lebih luas. Berdasarkan atas penilaian ini, dapat dibedakan bermacam-macam pengeluaran negara seperti: Pengeluaran yang self liquiditing sebagian atau seluruhnya, artinya pengeluaran pemerintah mendapatkan 
pembayaran kembali dari masyarakat yang menerima jasa-jasa barang-barang yang bersangkutan. Misalnya pengeluaran untuk jasa-jasa perusahaan negara, atau untuk proyekproyek produktif barang ekspor.

2. Pengeluaran yang reproduktif, artinya mewujudkan keuntungan-keuntungan ekonomis bagi masyarakat,yang dengan naiknya tingkat penghasilan masyarakat, akhirnya akan menaikkan penerimaan pemerintah. Misalnya pengeluaran untuk bidang pengairan, pertanian, pendidikan, kesehatan masyarakat (public health) maupun pembangunan di desa seperti kebijakan Dana Desa.

3. Pengeluaran yang tidak self liquditing maupun yang tidak reproduktif yaitu pengeluaran yang langsung menambah kegembiraan dan kesejahteraan masyarakat misalnya untuk bidang-bidang rekreasi, pendirian monumen, objek wisata dan sebagainya. Dan hal ini dapat juga mengakibatkan naiknya penghasilan nasional dalam arti jasa-jasa tadi.

4. Pengeluaran yang secara langsung tidak produktif dan merupakan pemborosan misalnya untuk pembiayaan pertahanan/ perang meskipun pada saat pengeluaran terjadi penghasilan perorangan yang menerimanya akan naik.

5. Pengeluaran yang merupakan penghematan di masa yang akan dating misalnya pengeluaran untuk anak-anak yatim piatu. Kalau hal ini tidak dijalankan sekarang, kebutuhan-kebutuhan pemeliharaan bagi mereka di masa mendatang pada waktu usia yang lebih lanjut pasti akan lebih besar.

\section{Desa}

Secara etimologi kata desa berasal dari bahasa Sansekerta, deca yang berarti tanah air, tanah asal, atau tanah kelahiran. Dari perspektif geografis, desa atau village yang diartikan sebagai " a groups of houses or shops in a country area, smaller than and town ". Desa adalah kesatuan masyarakat hukum yang memiliki kewewenangan untuk mengurus rumah tangganya berdasarkan hak asal-usul dan adat istiadat yang diakui dalam Pemerintahan Nasional dan berada di Daerah Kabupaten (Widjaya, 2003: t.h.). Sedangkan menurut Peraturan Pemerintah Nomor 72 Tahun 2005 Tentang Desa Pasal 1 menyebutkan bahwa Desa adalah kesatuan masyarakat hukum yang memiliki batas-batas wilayah yang berwenang untuk mengatur kepentingan masyarakat setempat, berdasarkan asal-usul dan adat istiadat setempat yang diakui dan dihormati dalam sistem Pemerintahan Negara Kesatuan Republik Indonesia.

\section{Dana Desa}

Sesuai dengan amanat Undang-Undang Dasar Negara Republik Indonesia Tahun 1945 (UUD 1945), pemerintah daerah berwenang mengatur dan mengurus sendiri urusan pemerintahan menurut asas otonomi dan tugas pembantuan. Pemberian otonomi kepada daerah diarahkan untuk mempercepat terwujudnya kesejahteraan masyarakat melalui peningkatan pelayanan publik, pemberdayaan, dan peran serta masyarakat dalam pembangunan di segala bidang kehidupan (Atmadja, 2009: t.h.). Selanjutnya, agar fungsi pemerintahan daerah terlaksana secara optimal, perlu diikuti dengan pemberian 
sumber-sumber penerimaan yang cukup kepada daerah, di samping kemampuan daerah sendiri dalam menggali sumber pendapatan daerah yang dapat dijadikan kekuatan dalam mempercepat pertumbuhan ekonomi.

Pada Pasal 67 ayat (2) Undang-Undang Nomor 6 Tahun 2014 Tentang Desa disebutkan bahwa desa memiliki kewajiban diantaranya yaitu meningkatkan kualitas kehidupan masyarakat desa, mengembangkan pemberdayaan masyarakat desa, serta memberikan dan meningkatkan pelayanan kepada masyarakat desa. Untuk mewujudkan apa yang menjadi kewajiban desa dan hak masyarakat desa, maka sangat diperlukan tersedianya dana untuk itu. Oleh karena itu, pemerintah melalui alokasi transfer kebijakan fiskal ke daerah, menetapkan kebijakan Dana Desa. Dana desa adalah dana yang bersumber dari APBN yang diperuntukkan bagi yang ditransfer melalui APBD kabupaten dan kota yang digunakan untuk membiayai penyelenggaraan pemerintahan, pelaksanaan pembangunan, pembinaan kemasyarakatan (PMK No. 241 Tahun 2014).

Berdasarkan Undang-Undang Nomor 6 Tahun 2014 tentang Desa, diberikan kewenangan untuk mengatur dan mengurus kewenangannya sesuai dengan kebutuhan dan prioritas desa. Hal itu berarti dana desa akan digunakan untuk menandai keseluruhan kewenangan sesuai dengan kebutuhan dan prioritas dana desa tersebut namun, mengingat dana desa bersumber dari Belanja Pusat, untuk mengoptimalkan penggunaan dana desa, Pemerintah diberikan kewenangan untuk menetapkan prioritas penggunaan dana desa untuk mendukung program pembangunan desa dan pemberdayaan masyarakat desa. Penetapan prioritas penggunaan dana tersebut tetap sejalan dengan kewenangan yang menjadi tanggungjawab desa.

Lebih lanjut, menurut Undang-Undang Nomor 6 Tahun 2014 tentang Desa pada Pasal 72 ayat (1) mengenai sumber pendapatan desa, dalam huruf d disebutkan "anggaran dana desa yang merupakan bagian dari dana perimbangan yang diterima Kabupaten/Kota". Selanjutnya dalam ayat (4) Pasal yang sama disebutkan "Anggaran Dana Desa sebagaimana dimaksud pada ayat (1) hurufd paling sedikit 10\% (sepuluh perseratus) dari dana perimbangan yang diterima Kabupaten/Kota dalam Anggaran Pendapatan dan Belanja Daerah setelah dikurangi Dana Alokasi Khusus". Berlakunya Undang-Undang Nomor 6 Tahun 2014 dirasakan menjadi angin segar bagi desa. Adanya Undang-Undang ini menjadi dasar hukum dari diakuinya desa sebagai suatu daerah otonomi sendiri. Dalam hubungannya dengan desentralisasi fiskal yang menjadi pokok dari berlakunya Undang-Undang tersebut yaitu terkait dengan $10 \%$ dana dari APBN untuk desa di seluruh Indonesia, dimana setiap desa akan menerima dana kurang lebih besar 1 milyar per tahun.

\section{Kemiskinan}

Dalam arti proper, kemiskinan dipahami sebagai keadaan kekurangan uang dan barang untuk menjamin kelangsungan hidup. Dalam arti luas. Chambers (dalam Chriswardani Suryawati, 2005) mengatakan bahwa kemiskinan adalah suatu integrated concept yang memiliki lima dimensi, yaitu: 1) kemiskinan (proper), 2) Analisis lntervensi Fiskal terhadap Kemiskinan |29 
ketidakberdayaan (powerless), 3) kerentanan menghadapi situasi darurat (state of emergency), 4) ketergantungan (dependence), dan 5) keterasingan (isolation), baik secara geografis maupun sosiologis. United Nations Development Programme (UNDP) mendefinisikan kemiskinan sebagai kelaparan, ketiadaan tempat berlindung, ketidakmampuan berobat ke dokter jika sakit, tidak mempunyai akses ke sekolah dan buta huruf, tidak mempunyai pekerjaan, takut akan masa depan, hidup dalam hitungan harian, ketidakmampuan mendapatkan air bersih, ketidakberdayaan, tidak ada keterwakilan dan kebebasan.

Dengan demikian, kemiskinan adalah keadaan dimana terjadi ketidakmampuan untuk memenuhi kebutuhan dasar seperti makanan, pakaian, tempat berlindung, pendidikan, dan kesehatan. Kemiskinan dapat disebabkan oleh kelangkaan alat pemenuh kebutuhan dasar, ataupun sulitnya akses terhadap pendidikan dan pekerjaan. Menurut Todaro dan Smith (2006), tinggi rendahnya tingkat kemiskinan di suatu negara tergantung pada dua faktor utama, yakni: tingkat pendapatan nasional rata-rata dan lebar sempitnya kesenjangan distribusi pendapatan. Setinggi apapun tingkat pendapatan nasional perkapita yang dicapai oleh suatu negara, selama distribusi pendapatannya tidak merata, maka tingkat kemiskinan di negara tersebut pasti akan tetap parah. Demikian pula sebaliknya, semerata apapun distribusi pendapatan di suatu negara, jika tingkat pendapatan nasional rata-ratanya rendah, maka kemiskinan juga akan semakin luas.

Menurut Sharp (dalam Kuncoro, 2006), terdapat tiga faktor penyebab kemiskinan jika dipandang dari sisi ekonomi. Pertama, kemiskinan muncul karena adanya ketidaksamaan pola kepemilikan sumberdaya yang menimbulkan distribusi pendapatan yang timpang. Penduduk miskin hanya memiliki sumberdaya yang terbatas dan kualitasnya rendah. Kedua, kemiskinan muncul akibat perbedaan dalam kualitas sumberdaya manusia. Kualitas sumberdaya manusia yang rendah berarti produktifitasnya rendah, yang pada gilirannya upahnya rendah. Rendahnya kualitas sumberdaya manusia ini karena rendahnya pendidikan, nasib yang kurang beruntung, adanya diskriminasi atau keturunan ketiga kemiskinan muncul karena perbedaan akses dalam modal.

Menurut BPS (Badan Pusat Statistik), garis kemiskinan didasarkan pada jumlah rupiah konsumsi berupa makanan, yaitu 2100 kalori per orang per hari (dari 52 jenis komoditi yang dianggap mewakili pola konsumsi penduduk yang berada di lapisan bawah), dan konsumsi nonmakanan (dari 45 jenis komoditi makanan sesuai kesepakatan nasional dan tidak dibedakan antara wilayah pedesaan dan perkotaan). Patokan kecukupan 2100 kalori ini berlaku untuk semua umur, jenis kelamin, dan perkiraan tingkat kegiatan fisik, berat badan, serta perkiraan status fisiologis penduduk, ukuran ini sering disebut dengan garis kemiskinan. Penduduk yang memiliki pendapatan di bawah garis kemiskinan dikatakan dalam kondisi miskin. Garis kemiskinan absolut sangat penting jika seseorang akan mencoba menilai efek dari kebijakan anti kemiskinan antar waktu, atau memperkirakan dampak dari suatu proyek terhadap kemiskinan (BPS, 2008). 


\section{METODE PENELITIAN}

Penelitian ini merupakan penelitian deskriptif kuantitatif. Pendekatan yang diambil adalah pendekatan kuantitatif. Pengambilan keputusan tersebut didasarkan pada hasil analisis yang dilakukan berdasarkan kajian teori dan hasil olah ekonometrika. Data yang dianalisis dalam penelitian ini adalah data sekunder berupa data panel. Data panel atau pooled data merupakan data yang terdiri atas data cross section dan data time series (Winarno, 2011), Data cross section pada penelitian ini adalah Kabupaten/Kota di Pulau Kalimantan yang mendapat alokasi Dana Desa, sedangkan data time series adalah tahun 2016 dan tahun 2017

\section{Operasional Variabel Penelitian}

Variabel Dependen dalam penelitian ini adalah kemiskinan, yang didefinisikan sebagai jumlah persentase penduduk miskin di Pulau Kalimantan dalam periode 2015-2017. Adapun tolak ukur Penduduk Miskin berdasarkan ketetapan BPS mengenai Garis Kemiskinan, yaitu menjumlahkan Garis Kemiskinan Makanan (GKM) dan Garis Kemiskinan Non-Makanan (GKNM). GKM adalah jumlah nilai pengeluaran dari 52 komoditi dasar makanan yang riil dikonsumsi penduduk yang kemudian disetarakan dengan 2100 kilokalori per kapita per hari. Sementara itu, GKNM merupakan penjumlahan nilai kebutuhan minimum dari komoditi-komoditi non-makanan terpilih, meliputi perumahan, sandang, pendidikan, dan kesehatan. (BPS, 2008)

Sementara Variabel Independen dalam penelitian ini adalah Kebijakan Fiskal Pemerintah yang direpresentasikan melalui Dana Desa. Dana Desa didefisinikan sebagai dari Alokasi APBN yang ditetapkan oleh Pemerintah Pusat melalui Peraturan Menteri Keuangan, Alokasi Dana Desa Paling sedikit $10 \%$ dari dari dana perimbangan yang diterima kab/kota dikurangi Dana Alokasi Khusus dan Bagian Dari PDRB Kabupaten/Kota paling sedikit $10 \%$.

\section{Model Fungsi}

Model fungsi yang akan digunakan untuk mengetahui pengaruh Dana Desa terhadap Kemiskinan Studi Kasus Pulau Kalimantan yaitu: Pit $=\alpha+\beta 1$ DDit $+\beta 2$ ADDIit $+\beta 3$ PDRBIit $+\mu$ it..

Dimana:

P : Kemiskinan

$\alpha \quad$ : Konstanta

DDit : Dana Desa bersumber dari APBN

ADDit : Dana Desa bersumber dari Dana Perimbangan Kab/Kota - DAK

PDRBit : Bagian Dari PDRB Kabupaten/ Kota paling sedikit 10\%.

$\beta 1,2 . . \mathrm{n} \quad$ : Koefisien Regresi

$\mu \mathrm{i} \quad$ : error term

Analisis data dilakukan dengan metode Common Effect, Fixed Effect, dan Random Effect, uji kriteria model menggunakan uji LM Breush-Pagan, uji Chow, dan uji Hausman. Uji statistik antara lain Uji t, Uji F, dan $\mathrm{R}^{2}$ (koefisien determinasi) untuk mengetahui bagaimanakah pengaruh variabel bebas terhadap vaiabel terikat secara simultan (serentak) maupun secara parsial (masing-masing variabel).

Analisis Intervensi Fiskal terhadap Kemiskinan | 31 
PEMBAHASAN DAN HASIL

\section{Uji Chow}

Untuk mengetahui model panel yang akan digunakan, maka digunakan uji F-Restricted dengan cara melihat nilai probabilitas ( $P$-Value) F-Statistik lebih kecil dari tingkat signifikansi $\alpha=$ $5 \%$. Sebelum melihat nilai probabilitas ( $P$-Value) F-Statistik lebih kecil dari tingkat signifikansi $\alpha=$
$5 \%$, terlebih dahulu dibuat hipotesisnya. Adapun hipotesisnya adalah sebagai berikut:

$$
\begin{aligned}
& \mathrm{H}_{\mathrm{o}} \quad \text { : Common Effect Model } \\
& \mathrm{H}_{\mathrm{i}} \quad \text { : Fixed Effect Model }
\end{aligned}
$$

Dari hasil berdasarkan metode Fixed Effect Model (FEM) dan Common Effect Model (CEM) diperoleh nilai probabilitas F-statistik yakni sebagai berikut:

Tabel 3.

Hasil Uji Chow

\begin{tabular}{llll}
\hline \hline Effects Test & Statistic & d.f. & Prob. \\
\hline \hline Cross-section F & 146.849698 & $(46,91)$ & 0.0000 \\
Cross-section Chi-square & 609.200778 & 46 & 0.0000 \\
\hline \hline
\end{tabular}

Sumber: Data diolah

Berdasarkan tabel 3 diatas diperoleh F-statistik adalah 146.849698 dengan d.f $(46,91)$ dan nilai probabilitas F-Statistik sebesar 0.0000, yang berarti bahwa nilai probabilitas F-Statistik lebih kecil dari tingkat signifikansi $\alpha$ 5\% $(0.0000<0.05)$. Maka $\mathrm{H}_{\mathrm{o}}$ ditolak, sehingga model panel yang digunakan berdasarkan Uji Chow adalah Fixed Effect Model.

\section{Uji Hausman}

Setelah melakukan pengujian untuk model CEM dan FEM, agar diketahui model panel yang akan diterapkan, selanjutnya dilakukan uji Hausman, pengujian ini untuk menentukan model paling tepat yang akan digunakan diantara FEM dan REM. Uji Hausman memberikan penilaian dengan menggunakan Chi-Square Statistic sehingga keputusan pemilihan model dapat ditentukan dengan tepat. Sebelum membandingkan Chi-square statistic dan Chisquare tabel terlebih dahulu dibuat hipotesisnya adalah sebagai berikut:

\section{$\mathrm{H}_{\mathrm{o}}$ : Random Effect Model \\ $\mathrm{H}_{\mathrm{i}} \quad$ : Fixed Effect Model}

Hasil pengolahan dengan uji Hausman dapat dilihat pada tabel berikut:

Tabel 4.

Hasil Uji Hausman

\begin{tabular}{llll}
\hline \hline Test Summary & Chi-Sq. Statistic & Chi-Sq. d.f. & Prob. \\
\hline \hline Cross-section random & 8.618868 & 3 & 0.0348 \\
\hline \hline
\end{tabular}

Sumber: Data diolah

Berdasarkan hasil uji Hausman pada tabel 4 di atas, didapatkan Chi-Square statistic sebesar 8.618868 dengan probabilitas 0.0348 dan d.f.
3. Dikarenakan nilai probabilitas Chi-Square statistic lebih kecil dari nilai $\alpha$ 5\% $0.0012<$ 0.05) maka $\mathrm{H}_{\mathrm{o}}$ ditolak. Dapat disimpulkan bahwa 
model terbaik yang dapat digunakan untuk model penelitian adalah Fixed Effect Model. Jadi, berdasarkan uji Chow dan uji Hausman model yang digunakan adalah Fixed Effect Model.

\section{Model Empiris}

Berdasarkan hasil dari estimasi yang menggunakan Fixed Effect Model dapat disimpulkan bahwa hasil regresi yang dihasilkan cukup baik untuk menjelaskan Analisis Intervensi Fiskal Terhadap Kemiskinan di Kabupaten/ Kota Pulau Kalimantan. Variabel Dana Desa, Alokasi dan Desa, dan Bagian PDRB Kabupaten/ Kota memiliki pengaruh negatif signifikan terhadap Kemiskinan di Kabupaten/Kota Pulau Kalimantan. Hal ini dapat dilihat dari Tabel 5 mengenai hasil estimasi uji di bawah ini:

Tabel 5.

Hasil Estimasi Fixed Effect Model

\begin{tabular}{lrr}
\hline Variabel & Koefisien & Prob./Value \\
\hline C & 12.40688 & 0.0000 \\
Dana Desa & -0.175515 & 0.0052 \\
Alokasi Dana Desa & -0.115200 & 0.0096 \\
PDRD & -0.019552 & 0.0206 \\
\hline R-Square & & 0.587599 \\
Adjusted R-Square & & 0.580922 \\
F-Statistic & & 147.9009 \\
Prob.(F-Statistic) & & 0.000000 \\
\hline
\end{tabular}

Sumber: Data diolah

Berdasarkan pengujian Fixed Effect Model pada tabel 4.3 di atas, dapat dijelaskan melalui persamaan sebagai berikut:

$$
\begin{aligned}
\mathrm{P}= & 12.40688-0.175515 \mathrm{DD}- \\
& 0.115200 \mathrm{ADD}-0.019552 \mathrm{PDRD}
\end{aligned}
$$

Dimana:

P : Jumlah persentase penduduk miskin di Pulau Kalimantan.
DD : Dana Desa yang bersumber dari APBN.

ADD : Alokasi Dana Desa yang bersumber dari Dana Perimbangan - DAK Kabupaten Kota di Pulau Kalimantan.

PDRD : Bagian Dari PDRB Kabupaten/Kota paling sedikit $10 \%$.

Tabel 6.

Individual Effect per Wilayah

\begin{tabular}{|c|l|r|r|l|r|}
\hline No. & Wilayah & Individual Effect & No. & Wilayah & Individual Effect \\
\hline 1 & Sambas & 2.077781 & 25 & Murung Raya & -0.620998 \\
\hline 2 & Bengkayang & 0.404419 & 26 & Tanah Laut & -2.257102 \\
\hline 3 & Landak & 5.863554 & 27 & Kota Baru & -2.229178 \\
\hline 4 & Mempawah & -1.261529 & 28 & Banjar & -3.592269 \\
\hline 5 & Sanggau & -2.260091 & 29 & Barito Kuala & -1.579555 \\
\hline 6 & Ketapang & 4.575915 & 30 & Tapin & -3.105482 \\
\hline 7 & Sintang & 3.202679 & 31 & Hulu Sungai Selatan & -0.692270 \\
\hline 8 & Kapuas Hulu & 2.947560 & 32 & Hulu Sungai Tengah & -0.823316 \\
\hline 9 & Sekadau & -0.609016 & 33 & Hulu Sungai Utara & -0.003628 \\
\hline 10 & Melawi & 5.747861 & 34 & Tabalong & -0.513924 \\
\hline 11 & Kayong Utara & 2.877584 & 35 & Tanah Bumbu & -1.580147 \\
\hline 12 & Kubu Raya & -1.657978 & 36 & Balangan & -1.140035 \\
\hline 13 & Kotawaringin Barat & -2.074953 & 37 & Paser & 2.101475 \\
\hline
\end{tabular}




\begin{tabular}{|r|l|r|l|l|r|}
\hline 14 & Kotawaringin Timur & -0.451698 & 38 & Kutai Barat & 1.839851 \\
\hline 15 & Kapuas & -1.061940 & 39 & Kutai Kartanegara & 1.079386 \\
\hline 16 & Barito Selatan & -2.250411 & 40 & Kutai Timur & 2.506914 \\
\hline 17 & Barito Utara & -1.433848 & 41 & Berau & -1.466630 \\
\hline 18 & Sukamara & -3.363181 & 42 & Penajam Paser Utara & 0.599473 \\
\hline 19 & Lamandau & -3.239054 & 43 & Mahakam Hulu & 3.811335 \\
\hline 20 & Seruyan & 1.088789 & 44 & Malinau & 0.612112 \\
\hline 21 & Katingan & -0.655904 & 45 & Bulungan & 2.174035 \\
\hline 22 & Pulang Pisau & -1.500022 & 46 & Tana Tidung & -0.811888 \\
\hline 23 & Gunung Mas & -0.969202 & 47 & Nunukan & -1.103509 \\
\hline 24 & Barito Timur & 0.798031 & & & \\
\hline
\end{tabular}

Sumber: Data diolah

Berdasarkan tabel 6 menunjukkan bahwa dari 47 kabupaten/kota yang menjadi objek penelitian, memiliki nilai individual effect yang berbeda beda, terdiri dari 29 kabupaten/kota individual effect negatif dan 18 kabupaten/kota dengan individual effect positif. Walaupun nilai individual effect antar individu berbeda-beda, namun nilai tersebut adalah sama atau tetap pada setiap waktu (fixed effect) (Gujarati: 2003). Apabila nilai dari variabel Dana Desa, Alokasi Dana Desa dan PDRD tersebut adalah nol (0), maka persentase dari jumlah penduduk miskin di setiap Kabupaten/Kota di Pulau Kalimantan adalah nilai dari individual effect tersebut.

\section{Uji-t}

Pengujian ini dilakukan untuk menguji apakah variabel independen (Dana Desa, Alokasi Dana Desa dan PDRD) berpengaruh secara parsial terhadap variabel dependennya Persentase Penduduk Miskin di Kabupaten/Kota Pulau Kalimantan, yaitu dengan membandingkan masing-masing nilai t-statistik dari regresi dengan t-tabel dalam menolak atau menerima hipotesis. Pada tingkat keyakinan $\alpha=5 \%$ dengan jumlah observasi sebanyak 141, maka diperoleh t-tabel sebesar 1.97693.

Tabel 7.

Hasil Uji-t

\begin{tabular}{lrrr}
\hline \multicolumn{1}{c}{ Variabel } & t-Statitic & t-Tabel & \multicolumn{1}{c}{ Probabilitas } \\
\hline Dana Desa & 2.862886 & 1.97693 & 0.0052 \\
Alokasi Dana Desa & 2.087733 & 1.97693 & 0.0096 \\
PDRD & 2.227443 & 1.97693 & 0.0206 \\
\hline
\end{tabular}

Sumber: Data diolah

Berdasarkan hasil regresi yang diperoleh pada model empiris maka pembuktian dari hipotesis yang telah dipaparkan adalah sebagai berikut:

1. Variabel Dana Desa memiliki t-statistic $>$ t-tabel $(2.862886>1.97693)$ atau nilai probabilitas dari variabel Dana Desa lebih kecil dari tingkat keyakinan $\alpha=5 \%(0.0052<0.05)$ yang berarti variabel Dana Desa berpengaruh signifikan terhadap Persentase Penduduk Miskin di Kabupaten/Kota Pulau Kalimantan.

2. Variabel Alokasi Dana Desa memiliki t-statistic $>$ t-tabel $(2.087733>1.97693)$ atau nilai probabilitas dari variabel Alokasi Dana Desa lebih kecil dari tingkat keyakinan $\alpha=5 \%(0.0096<0.05)$ yang berarti variabel Alokasi Dana Desa berpengaruh signifikan 
terhadap Persentase Penduduk Miskin di Kabupaten/Kota Pulau Kalimantan.

3. Variabel PDRD memiliki t-statistic $>\mathrm{t}$-tabel $(2.087733>1.97693)$ atau nilai probabilitas dari variabel PDRD lebih kecil dari tingkat keyakinan $\alpha=5 \%(0.0206<0,05)$ yang berarti variabel PDRD berpengaruh signifikan terhadap Persentase Penduduk Miskin di Kabupaten/Kota Pulau Kalimantan.

\section{Uji F}

Untuk menguji apakah variabel independen berpengaruh secara simultan (bersama-sama) terhadap variabel dependennya, maka digunakan uji-F dengan cara membandingkan F-statistik dengan F-tabel.

Tabel 8

Hasil Uji-f

\begin{tabular}{|l|l|l|}
\hline F-Statitic & F-Tabel & Probabilitas \\
\hline 14.79009 & 2.44 & 0.00000 \\
\hline
\end{tabular}

Sumber: Data diolah

Berdasarkan tabel 8 di atas, hasil regresi data panel menggunakan Fixed Effect Model diperoleh nilai F-statistik sebesar 14,79009 dengan probabilitas sebesar 0,00000 , pada tingkat keyakinan $\alpha=5 \%, k=3, n=141$, sehingga diperoleh F-tabel dengan nilai df yaitu $(2,44)$. Maka terlihat bahwa F-statistik > F-tabel $(14,79009>2.67)$ atau nilai probabilitas F-statistik lebih kecil dari tingkat signifikansi $\alpha 5 \%(0,0000<0,05)$, artinya bahwa variabel independen (Dana Desa, Alokasi Dana Desa dan PDRD) secara bersama-sama berpengaruh signifikan terhadap Persentase Penduduk Miskin di Kabupaten/Kota Pulau Kalimantan.

\section{Uji Koefisien Determinasi}

Berdasarkan hasil regresi data panel menggunakan Fixed Effect Model didapatkan koefisien determinasi sebesar 0,5875799 atau 58,75\%. Hal ini menunjukkan bahwa hanya 58,75\% Persentase Penduduk Miskin di Pulau Kalimantan dapat dijelaskan oleh variabel Dana Desa, Alokasi Dana Desa dan PDRD. Sedangkan sisanya 42,25\% dijelaskan oleh variabel lain yang tidak diteliti dalam penelitian ini.

\section{Kebijakan Fiskal dan Kemiskinan}

Ravallion \& Datt (2002), menyatakan bahwa untuk mengentaskan kemiskinan sekaligus menurunkan ketimpangan dapat dilakukan dengan meningkatkan pertumbuhan pro poor, yaitu pertumbuhan ekonomi yang memihak kepada penduduk miskin, dimana mayoritas penduduk miskin tinggal di pedesaan. Untuk mendorong pertumbuhan pro poor inilah diperlukan sarana dan prasarana atau infrastruktur yang memadai. Dengan kata lain, diperlukan transfer fiskal yang dikhususkan untuk pembangunan ekonomi pada sektor pedesaan, untuk itulah pemerintah pusat mengeluarkan kebijakan Dana Desa disertai dengan Alokasi Dana Desa dan bagian dari PDRB Kabupaten/ Kota tempat desa bernaung.

Namun kemiskinan tidak hanya ditengarai oleh kurangnya akses terhadap finansial. Kemiskinan struktural, bersebab dari kondisi struktur ekonomi, atau dengan kata lain tatanan kehidupan yang tak menguntungkan (Suyanto, dalam BPS, 2008). Di dalam kondisi struktur yang Analisis lntervensi Fiskal terhadap Kemiskinan |35 
demikian itu kemiskinan menggejala bukan oleh sebab-sebab yang alami atau oleh sebab-sebab yang pribadi, melainkan oleh sebab tatanan ekonomi yang tak adil. Tatanan yang tak adil ini menyebabkan banyak warga masyarakat gagal memperoleh peluang dan/atau akses untuk mengembangkan dirinya serta meningkatkan kualitas hidupnya, sehingga mereka yang malang dan terperangkap ke dalam perlakuan yang tidak adil ini menjadi serba berkekurangan, tak setara dengan tuntutan untuk hidup yang layak dan bermartabat sebagai manusia. Kasusnya adalah kemiskinan di area pedesaan, minimnya pemerataan perekonomian di pedesaan membuat struktur ekonomi di pedesaan cenderung kurang. Oleh karena itu, dibutuhkan kebijakan inklusifitas finansial atau perekonomian di daerah pedesaan melalui intervensi kebijakan fiskal yaitu melalui Dana Desa.
Berdasarkan tabel 2, rata-rata kemiskinan di Pulau Kalimantan memang menjadi yang terendah dibanding dengan wilayah-wilayah lain pada tahun 2015-2017 Peningkatan jumlah Dana Desa ini tidak sebanding dengan penurunan persentase penduduk miskin yang ada di Pulau Kalimantan. Table 9 menunjukkan jumlah Dana Desa yang berasal dari APBN yang diterima per Provinsi (jumlah yang diterima di setiap kabupaten/kota di provinsi tersebut). Pada tahun 2015 hingga 2017, terjadi kenaikan yang cukup besar dari besaran Dana Desa ini. Sementara bila merujuk kepada tabel 2, persentase penduduk miskin di Pulau Kalimantan pada tahun 2015 sebesar 6,62\%, menurun menjadi 6,46\% pada tahun 2016 dan tetap pada angka 6,46\% pada tahun 2017. Artinya, hanya terjadi penurunan persentase penduduk miskin sebesar $0,16 \%$ selama 3 tahun penganggaran Dana Desa.

Tabel 9.

Jumlah Dana Desa Pulau Kalimantan (Ribu Rupiah)

\begin{tabular}{|l|l|l|l|}
\hline \multicolumn{1}{|c|}{ Provinsi } & Jumlah Dana Desa 2015 & Jumlah Dana Desa 2016 & Jumlah Dana Desa 2017 \\
\hline Kalimantan Barat & 537.066 .678 & 1.241 .607 .506 & 1.626 .725 .259 \\
\hline Kalimantan Tengah & 403.351 .015 & 904.370 .668 & 1.148 .904 .929 \\
\hline Kalimantan Selatan & 501.119 .950 & 1.125 .244 .835 & 1.430 .375 .412 \\
\hline Kalimantan Timur & 240.542 .413 & 540.759 .158 & 692.420 .247 \\
\hline Kalimantan Utara & 129.874 .894 & 291.096 .987 & 369.938 .349 \\
\hline
\end{tabular}

Sumber: Direktorat Jenderal Perimbangan Kemenkeu, 2018

Sementara itu, jika melihat hasil penelitian yang menyatakan bahwa pengaruh dari variabel independen terhadap variabel Persentase Penduduk Pulau Kalimantan miskin masih kecil (Dana Desa -0.175515, Alokasi Dana Desa -0.115200, PDRD -0.019552). Kedua hal ini ini (Data Statistik dan Hasil Ekonometrik) dapat disebabkan oleh beberapa hal, antara lain kurang tepatnya penyaluran Dana Desa tersebut atau disebabkan oleh kemiskinan non struktural, atau dengan kata lain kemiskinan kultural yang ada di masyarakat Pulau Kalimantan. Jika kemikinan struktural diakibatkan oleh tidak meratanya pembangunan ekonomi, kemiskinan kultural diakibatkan oleh faktor-faktor adat dan budaya suatu daerah tertentu yang membelenggu seseorang tetap melekat dengan indikator kemiskinan. Menurut Suyanto (dalam BPS, 2008) indikator kemiskinan tersebut bisa dikurangi atau bahkan secara bertahap bisa dihilangkan dengan 
mengabaikan faktor-faktor adat dan budaya tertentu yang menghalangi seseorang melakukan perubahan-perubahan ke arah tingkat kehidupan yang lebih baik. Kemiskinan karena tradisi sosiokultural terjadi pada suku-suku terasing, seperti halnya suku Dayak di pedalaman Kalimantan.

\section{PENUTUP}

\section{Kesimpulan}

Pemerintah sebagai penanggung jawab utama perekonomian bangsa sadar betul akan pentingnya pemerataan pembangunan, oleh karena itu melalui intervensi fiskal melalui kebijakan Dana Desa dan didukung oleh Alokasi Dana Desa serta bagian PDRD Kabupaten/Kota diharapkan mampu menciptakan pembangunan yang merata di setiap desa di Indonesia. Kebijakan Dana Desa memang menjadi instrumen fiskal yang baik untuk menyelenggarakan pemerintahan desa yang partisipatif. Dengan adanya instrument tersebut, Desa diharapkan dapat memecahkan masalah yang terdapat pada wilayahnya sendiri. Namun, secara umum, intervensi fiskal ini selama tahun 2015-2017 pada Kabupaten/Kota di Pulau Kalimantan dapat dikatakan masih memiliki hasil yang belum memuaskan. Penurunan persentase jumlah penduduk miskin yang masih jauh di bawah angka $1 \%$ per tahun adalah hal yang perlu menjadi perhatian khusus terkait pengelolaan Dana Desa.

\section{Saran}

Paper ini memiliki keterbatasan, yaitu hanya mengulas besarnya Dana Desa terhadap Persentase Penduduk Miskin, namun belum mengulas bagaimana pengelolaan dan tingkat partisipasi masyarakat. Lebih lanjut, paper ini juga hanya menentukan kemiskinan berdasarkan persentase penduduk miskin di bawah garis kemiskinan pada kemiskinan struktural, tidak menyertakan aspek kemiskinan kultural. Variabel yang diteliti sangat terbatas sehingga perlu kajian lanjutan dengan memasukan beberapa variabel lain yang terkait dengan aspek model perencanaan wilayah desa dan kelembagaan desa. Oleh karena itu disarankan kepada peneliti selanjutnya untuk menjadikan paper ini sebagai rujukan bagi penelitian-penelitian mengenai pengaruh intervensi fiskal terhadap kemiskinan pada umumnya, dan penelitian terkait dana desa pada khususnya.

\section{DAFTAR KEPUSTAKAAN}

Adhi, I Made Kerta. 2016. Faktor-kaktor Penyebab Kemiskinan Kultural dan Model Pengentasan Berbasis Kearifan Lokal: Studi pada Masyarakat Miskin di Pegunungan Kintamani, Bali. Jurnal Kajian Bali Vol. 06, No. 02, Oktober 2016

Ayu, Dwisuci dan Fahmi Wibawa.2012. Desentralisasi Fiskal dan Pengaruhnya Terhadap Pertumbuhan Ekonomi Di Propinsi Yogyakarta. Jurnal Signifikan Vol. 1 No. 1 April 2012

Badan Pusat Statistik. 2018. Persentase Penduduk Miskin Per Kabupaten Kota di Indonesia 20152017. Jakarta: BPS

Badan Pusat Statistik. 2008. Analisis Kemiskinan Indonesia 2008. Jakarta: BPS

Direktorat Jenderal Perimbangan Kementerian Keuangan. 2015. Lampiran Dana Desa Tahun 2015. Jakarta: Kemeterian Keuangan

Analisis lntervensi Fiskal terhadap Kemiskinan | 37 
JURNAL IMARA

Direktorat Jenderal Perimbangan Kementerian Keuangan. (2016). Lampiran Dana Desa Tahun 2016. Jakarta: Kemeterian Keuangan

Direktorat Jenderal Perimbangan Kementerian Keuangan. (2017). Lampiran Dana Desa Tahun 2017. Jakarta: Kemeterian Keuangan

Gujarati, Damodar. 2003. Dasar Ekonometrik. Jakarta: Penerbit Erlangga

Kuncoro, Mudrajad. 2006. Otonomi \& Pembangunan Daerah. Jakarta: Penerbit Erlangga.

Peraturan Menteri Keuangan (PMK) 214 Tahun 2014 tentang Pelaksanaan Pertanggungjawaban Transfer ke Daerah dan Dana Desa

Peraturan Pemerintah Nomor 72 Tahun 2005 tentang Desa

Ravallion, M., \& Datt, G. 2002. Why has economic growth been more pro-poor in some states of India than others? Journal of Development Economics, 68(2), 381-400. https://doi. org/10.1016/S0304-3878(02)00018-4
Suparmoko. 2002. Ekonomi PublikUntuk Keuangan dan Pembangunan Daerah. Yogyakarta: Penerbit Andi.

Todaro, Michael P. 2006. Pembangunan Ekonomi di Dunia Ketiga Jilid ke-3. Jakarta: Penerbit Erlangga

Undang-Undang Dasar Negara Republik Indonesia Tahun 1945

Undang Undang Nomor 17 Tahun 2003 tentang Keuangan Negara

Undang Undang Nomor 33 Tahun 2004 tentang Perimbangan Keuangan

Widjaja, HAW. 2003. Otonomi Desa. Jakarta: Rajawali Pers

Winaryo,WingWahyu. 2011.Analisis ekonometrika dan statistika dengan Eviews Edisi Kelima. Yogyakarta: Sekolah Tinggi Ilmu Menejemen YKPN

World Bank. 2008 World Development Report 2008: Making Service Work for Poor People, IBRD/ The World Bank, Washington DC. 